\title{
Strain-level genetic diversity of Methylophaga nitratireducenticrescens confers plasticity to denitrification capacity in a methylotrophic marine denitrifying biofilm
}

\author{
Valérie Geoffroy ${ }^{1,2}$, Geneviève Payette ${ }^{1}$, Florian Mauffrey ${ }^{3}$, Livie Lestin ${ }^{1}$, Philippe Constant $^{1}$, Richard \\ Villemur Corresp. 1 \\ 1 Institut Armand-Frappier, Institut National de la Recherche Scientifique, Laval, Québec, Canada \\ 2 Lallemand, Montreal, Québec, Canada \\ 3 Laboratoire de santé publique du Québec, Ste-Anne-de-Bellevue, Québec, Canada \\ Corresponding Author: Richard Villemur \\ Email address: richard.villemur@iaf.inrs.ca
}

Background. The biofilm of a methanol-fed, fluidized denitrification system treating a marine effluent is composed of multi-species microorganisms, among which Hyphomicrobium nitrativorans NL23 and Methylophaga nitratireducenticrescens JAM1 are the principal bacteria involved in the denitrifying activities. Strain NL23 can carry complete nitrate $\left(\mathrm{NO}_{3}{ }^{-}\right)$reduction to $\mathrm{N}_{2}$, whereas strain JAM1 can perform 3 out of the 4 reduction steps. A small proportion of other denitrifiers exists in the biofilm, suggesting the potential plasticity of the biofilm in adapting to environmental changes. Here, we report the acclimation of the denitrifying biofilm from continuous operating mode to batch operating mode, and the isolation and characterization from the acclimated biofilm of a new denitrifying bacterial strain, named GP59.

Methods. The denitrifying biofilm was batch-cultured under anoxic conditions. The acclimated biofilm was plated on Methylophaga specific medium to isolate denitrifying Methylophaga isolates. Planktonic cultures of strains GP59 and JAM1 were performed, and the growth and the dynamics of $\mathrm{NO}_{3}{ }^{-}$, nitrite $\left(\mathrm{NO}_{2}{ }^{-}\right)$and $\mathrm{N}_{2} \mathrm{O}$ were determined. The genomes of strains GP59 and JAM1 were sequenced and compared. The transcriptomes of strains GP59 and JAM1 were derived from anoxic cultures.

Results. During batch cultures of the biofilm, we observed the disappearance of $\mathrm{H}$. nitrativorans NL23 without affecting the denitrification performance. From the acclimated biofilm, we isolated strain GP59 that can perform, like $H$. nitrativorans NL23, the complete denitrification pathway. The GP59 cell concentration in the acclimated biofilm was 2-3 orders of magnitude higher than $M$. nitratireducenticrescens JAM1 and $H$. nitrativorans NL23. Genome analyses revealed that strain GP59 belongs to the species M. nitratireducenticrescens. The GP59 genome shares more than $85 \%$ of its coding sequences with those of strain JAM1. Based on transcriptomic analyses of anoxic cultures, most of these common genes in strain GP59 were expressed at similar level than their counterparts in strain JAM1. In contrast to strain JAM1, strain GP59 cannot reduce $\mathrm{NO}_{3}{ }^{-}$under oxic culture conditions, and has a 24-h lag time before growth and $\mathrm{NO}_{3}{ }^{-}$reduction start to occur in anoxic cultures, suggesting that both strains regulate differently the expression of their denitrification genes. Strain GP59 has the ability to reduce $\mathrm{NO}_{2}^{-}$as it carries a gene encoding a Nirk-type $\mathrm{NO}_{2}^{-}$reductase. Based on the CRISPR sequences, strain GP59 did not emerge from strain JAM1 during the biofilm batch cultures but rather was present in the original biofilm and was enriched during this process.

Discussion. These results reinforce the unique trait of the species $M$. nitratireducenticrescens among the Methylophaga genus as facultative anaerobic bacterium. These findings also showed the plasticity of denitrifying population of the biofilm in adapting to anoxic marine environments of the bioreactor. 


\section{Title}

2 Strain-level genetic diversity of Methylophaga nitratireducenticrescens confers plasticity to

3 denitrification capacity in a methylotrophic marine denitrifying biofilm

4

\section{Authors}

6 Valérie Geoffroy $^{1,2}$, Geneviève Payette ${ }^{1}$, Florian Mauffrey ${ }^{1,3}$, Livie Lestin ${ }^{1}$, Philippe Constant ${ }^{1}$,

$7 \quad$ Richard Villemur ${ }^{1}$

8

9 Addresses

10 1INRS-Institut Armand-Frappier, Laval, Québec, Canada

11 2Present address: Lallemand, Montreal, Québec, Canada

12 3Present address: Laboratoire de santé publique du Québec, Ste-Anne-de-Bellevue, Québec,

13 Canada

14 Corresponding author.

15 Richard Villemur, richard.villemur@iaf.inrs.ca 


\section{Abstract}

18 Background. The biofilm of a methanol-fed, fluidized denitrification system treating a marine

19 effluent is composed of multi-species microorganisms, among which Hyphomicrobium nitrativorans NL23 and Methylophaga nitratireducenticrescens JAM1 are the principal bacteria

21 involved in the denitrifying activities. Strain NL23 can carry complete nitrate $\left(\mathrm{NO}_{3}{ }^{-}\right)$reduction 22 to $\mathrm{N}_{2}$, whereas strain JAM1 can perform 3 out of the 4 reduction steps. A small proportion of 23 other denitrifiers exists in the biofilm, suggesting the potential plasticity of the biofilm in 24 adapting to environmental changes. Here, we report the acclimation of the denitrifying biofilm 25 from continuous operating mode to batch operating mode, and the isolation and characterization 26 from the acclimated biofilm of a new denitrifying bacterial strain, named GP59.

28 Methods. The denitrifying biofilm was batch-cultured under anoxic conditions. The acclimated 29 biofilm was plated on Methylophaga specific medium to isolate denitrifying Methylophaga 30 isolates. Planktonic cultures of strains GP59 and JAM1 were performed, and the growth and the 31 dynamics of $\mathrm{NO}_{3}^{-}$, nitrite $\left(\mathrm{NO}_{2}^{-}\right)$and $\mathrm{N}_{2} \mathrm{O}$ were determined. The genomes of strains GP59 and 32 JAM1 were sequenced and compared. The transcriptomes of strains GP59 and JAM1 were 33 derived from anoxic cultures.

35 Results. During batch cultures of the biofilm, we observed the disappearance of $H$. nitrativorans

36 NL23 without affecting the denitrification performance. From the acclimated biofilm, we 37 isolated strain GP59 that can perform, like H. nitrativorans NL23, the complete denitrification 38 pathway. The GP59 cell concentration in the acclimated biofilm was 2-3 orders of magnitude 
39 higher than $M$. nitratireducenticrescens JAM1 and $H$. nitrativorans NL23. Genome analyses

40 revealed that strain GP59 belongs to the species M. nitratireducenticrescens. The GP59 genome

41 shares more than $85 \%$ of its coding sequences with those of strain JAM1. Based on

42 transcriptomic analyses of anoxic cultures, most of these common genes in strain GP59 were

43 expressed at similar level than their counterparts in strain JAM1. In contrast to strain JAM1,

44 strain GP59 cannot reduce $\mathrm{NO}_{3}{ }^{-}$under oxic culture conditions, and has a 24-h lag time before

45 growth and $\mathrm{NO}_{3}{ }^{-}$reduction start to occur in anoxic cultures, suggesting that both strains regulate

46 differently the expression of their denitrification genes. Strain GP59 has the ability to reduce

$47 \mathrm{NO}_{2}^{-}$as it carries a gene encoding a NirK-type $\mathrm{NO}_{2}^{-}$reductase. Based on the CRISPR

48 sequences, strain GP59 did not emerge from strain JAM1 during the biofilm batch cultures but

49 rather was present in the original biofilm and was enriched during this process.

51 Discussion. These results reinforce the unique trait of the species M. nitratireducenticrescens

52 among the Methylophaga genus as facultative anaerobic bacterium. These findings also showed

53 the plasticity of denitrifying population of the biofilm in adapting to anoxic marine environments

54 of the bioreactor. 


\section{Introduction}

Denitrification describes the successive reduction of nitrate $\left(\mathrm{NO}_{3}^{-}\right)$to nitrite $\left(\mathrm{NO}_{2}^{-}\right)$,

57 nitric oxide $(\mathrm{NO})$, nitrous oxide $\left(\mathrm{N}_{2} \mathrm{O}\right)$, and nitrogen $\left(\mathrm{N}_{2}\right)(1)$. This process is used by bacteria for

58 respiration in environments with low oxygen concentrations and with $\mathrm{NO}_{3}{ }^{-}, \mathrm{NO}_{2}{ }^{-}, \mathrm{NO}$, and $\mathrm{N}_{2} \mathrm{O}$ as electron acceptors. The process is driven by metalloenzymes $\mathrm{NO}_{3}{ }^{-}$reductase, $\mathrm{NO}_{2}{ }^{-}$reductase, NO reductase, and $\mathrm{N}_{2} \mathrm{O}$ reductase (2). As a facultative trait, denitrification occurs frequently across environments, and is performed by bacteria of diverse origins (3). Furthermore, numerous microorganisms carry incomplete denitrification pathways for either their growth or detoxification, as $\mathrm{NO}_{2}{ }^{-}$and $\mathrm{NO}$ are deleterious molecules (4-7).

Several studies were carried out in our laboratory on a naturally-occurring multispecies denitrifying biofilm that has developed in a methanol-fed, fluidized denitrification continuous system that treated recirculating water of a marine aquarium at the Montreal Biodome. The

67 biofilm consists of at least 15 bacterial species and numerous protozoans $(8,9)$, among which Methylophaga spp. and Hyphomicrobium spp. compose more than 50\% of the biofilm (10). Rissanen et al. (11) also observed the combination of Methylophaga spp. and Hyphomicrobium spp. in the fluidized-bed type denitrification reactors treating the recirculating seawater of the

71 public fish aquarium SEA LIFE at Helsinki, Finland, suggesting the importance of these two 72 genera in marine denitrification processes.

We isolated Hyphomicrobium nitrativorans NL23 and Methylophaga

nitratireducenticrescens JAM1 from the biofilm of the Biodome denitrification system and 75 showed they are the main actors of the denitrifying activities $(8,12-15)$. H. nitrativorans NL23 can carry out complete $\mathrm{NO}_{3}{ }^{-}$reduction to $\mathrm{N}_{2}$, whereas $M$. nitratireducenticrescens JAM1 can perform 3 out of the 4 reduction steps; it misses the reduction of $\mathrm{NO}_{2}{ }^{-}$to $\mathrm{NO}$ (16-20). In addition 
to $H$. nitrativorans NL23 and $M$. nitratireducenticrescens JAM1, we have demonstrated that a small proportion of other denitrifiers exists in the biofilm of the Biodome denitrification system (13), suggesting the potential plasticity of the biofilm in adapting to environmental changes.

Methylophaga species are halophilic marine methylotrophic gammaproteobacteria that do not grow in the absence of $\mathrm{NaCl}$ and use one-carbon compounds (e.g. methanol) as sole carbon and energy sources with carbon assimilation proceeding via the 2-keto-3-deoxy-6phosphogluconate (KDPG)-variant ribulose monophosphate (RuMP) pathway $(15,21)$. The operating conditions of the Biodome denitrification process led to the enrichment of $M$. nitratireducenticrescens JAM1 in the biofilm, which is the only reported isolated Methylophaga species that can grow under anoxic conditions with $\mathrm{NO}_{3}{ }^{-}$or $\mathrm{N}_{2} \mathrm{O}$ as sole electron acceptors (12, 18, 19). This trait is correlated with the presence in the genome of two gene clusters encoding dissimilatory $\mathrm{NO}_{3}{ }^{-}$reductases (narGHJI, referred as narl and nar2), two gene clusters encoding cytochrome $b c$-type complex NO reductases (referred as cnorl and cnor2) and one gene cluster encoding a dissimilatory $\mathrm{N}_{2} \mathrm{O}$ reductase $($ nos $)(15,19)$. M. nitratireducenticrescens JAM1 lacks a gene encoding a dissimilatory copper- (NirK) or cytochrome cd1-type (NirS) $\mathrm{NO}_{2}{ }^{-}$reductase.

Our group has also investigated the potential of using the batch operating mode for the denitrification system instead of the continuous one as it prevailed at the Montreal Biodome. With this mode, a better real-time control was obtained to avoid sulfate-reduction that can be easily occurring in seawater biotreatments (22). In this report, we aim to assess the impact of the batch operating mode on the bacterial population of the denitrifying biofilm. We observed the disappearance of $H$. nitrativorans NL23 without the loss of the denitrifying activities during the biofilm acclimation to this mode. We hypothesized that new denitrifiers were enriched during the biofilm acclimation, which displaced $H$. nitrativorans NL23. From this biofilm, a new 
101 denitrifying bacterial strain, named GP59, was isolated that is closely related to $M$.

102 nitratireducenticrescens JAM1. We compared strain GP59 with M. nitratireducenticrescens

103 JAM1 at the physiological, genomic and transcriptomic levels. Genomic data were also

104 compared with available genomes of Methylophaga species. Our results present new insights of

105 M. nitratireducenticrescens under anoxic environments. They also provide indications that

106 strain-level genomic heterogeneities can influence the dynamism of the biofilm microbial

107 population in adapting to new operating conditions.

108

109 Material and Methods

110

$111 \mathrm{NO}_{3}{ }^{-}, \mathrm{NO}_{2}^{-}$and $\mathrm{N}_{2} \mathrm{O}$ measurements

112 Measurements of $\mathrm{NO}_{3}{ }^{-}, \mathrm{NO}_{2}^{-}$and $\mathrm{N}_{2} \mathrm{O}$ concentrations in all biofilm and planktonic cultures

113 were performed using ion chromatography as described in Mauffrey et al. (18).

114

115 Biofilm acclimation

116 Artificial seawater (ASW) medium was composed of (for 1 liter solution): $27.5 \mathrm{~g} \mathrm{NaCl}$,

$11710.68 \mathrm{~g} \mathrm{MgCl}_{2} * 6 \mathrm{H}_{2} \mathrm{O}, 2 \mathrm{~g} \mathrm{MgSO}_{4} * 7 \mathrm{H}_{2} \mathrm{O}, 1 \mathrm{~g} \mathrm{KCl}, 0.5 \mathrm{~g} \mathrm{CaCl}_{2}, 456 \mu \mathrm{L}$ of $\mathrm{FeSO}_{4} * 7 \mathrm{H}_{2} \mathrm{O} 4 \mathrm{~g} / \mathrm{L}, 5$

$118 \mathrm{~mL}$ of $\mathrm{KH}_{2} \mathrm{PO}_{4} 51.2 \mathrm{~g} / \mathrm{L}, 5 \mathrm{~mL}$ of $\mathrm{Na}_{2} \mathrm{HPO}_{4} 34 \mathrm{~g} / \mathrm{L}$. It was supplemented with $1 \mathrm{~mL}$ of trace

119 elements (master solution: $\mathrm{FeSO}_{4} * 7 \mathrm{H}_{2} \mathrm{O} 0.9 \mathrm{~g} / \mathrm{L}, \mathrm{CuSO}_{4} * 5 \mathrm{H}_{2} \mathrm{O} 0.03 \mathrm{~g} / \mathrm{L}$ and $\mathrm{MnSO}_{4} * \mathrm{H}_{2} \mathrm{O} 0.2$

$120 \mathrm{~g} / \mathrm{L})(23)$ and $\mathrm{NaNO}_{3}(21.4 \mathrm{mM}$ or $300 \mathrm{mg}-\mathrm{N} / \mathrm{L})$. The $\mathrm{pH}$ was adjusted $(\mathrm{NaOH})$ at 8.0. Three

121 120-mL vials containing each 20 unused « Bioflow $9 \mathrm{~mm}$ » carriers (Rauschert, Steinwiessen,

122 Germany) and $60 \mathrm{~mL}$ of ASW were purged of oxygen for 10 min with pure nitrogen gas $\left(\mathrm{N}_{2}\right.$,

123 purity $>99.9 \%$; Praxair, Mississauga, ON, Canada), sealed with sterile septum caps and 
124 autoclaved. Prior use, these carriers were washed with $\mathrm{HCl} \mathrm{10 \%} \mathrm{(v/v)} \mathrm{for} 3 \mathrm{~h}$, rinsed with water

125 and autoclaved. A $90 \mu \mathrm{L}$ volume $(72 \mathrm{mg})$ of filtered-sterilized methanol was then added to the

126 vials $(0.15 \% \mathrm{v} / \mathrm{v}$ final concentration).

127 Carriers (Bioflow $9 \mathrm{~mm}$ ) with the denitrifying biofilm were taken from the denitrification

128 system at the Montreal Biodome and frozen at $-20^{\circ} \mathrm{C}$ in seawater with $20 \%$ glycerol (24) until

129 use. The biomass from several frozen carriers was thawed, scrapped, weighted and dispersed in

130 the ASW medium at $0.08 \mathrm{~g}$ (wet weight) $/ \mathrm{mL}$. The biomass $(5 \mathrm{~mL} / \mathrm{vial}, 0.4 \mathrm{~g}$ of biofilm) was then

131 distributed with a syringe and an $18_{\mathrm{G}} 1 \frac{1}{2}$ needle to 3 vials. The vials were incubated at room

132 temperature and $100 \mathrm{rpm}$ with an orbital shaker in the dark. In average once a week, the vial was

133 opened in ambient air, the carriers were taken, gently washed with ASW medium to remove the

134 excess medium and the free bacteria, then transferred into vials with fresh anoxic medium, and

135 incubated in the same conditions (Fig. S1). Methanol and $\mathrm{NO}_{3}{ }^{-}$were added when needed if $\mathrm{NO}_{3}{ }^{-}$

136 was completely depleted during the week. After the $5^{\text {th }}$ transfer, the biofilm was collected and

137 referred to in the text as the acclimated biofilm. One part was preserved in $15 \%$ glycerol at $-70^{\circ} \mathrm{C}$

138 for further used such as DNA extraction (see below). The other part was used to isolate bacterial

139 isolates (next subsection).

140

141 Isolation of Methylophaga sp. strain GP59

142 The acclimated biofilm was dispersed in saline solution $(3 \% \mathrm{NaCl}, 34.2 \mathrm{mM}$ phosphate

143 buffer $\mathrm{pH}$ 7.4), and serial dilutions were made and inoculated onto the Methylophaga medium

1441403 (American Type Culture Collection [ATCC], Manassas, VA, USA) supplemented with

$1451.5 \%$ agar and $0.3 \% \mathrm{v} / \mathrm{v}$ methanol. The plates were incubated at $30^{\circ} \mathrm{C}$ for no more than 7 days,

146 under oxic conditions (no $\mathrm{NO}_{3}{ }^{-}$) or under anoxic conditions in anoxic jars with a gaspak $\left(\mathrm{BBL}^{\mathrm{TM}}\right.$ 
147 GasPak ${ }^{\mathrm{TM}}$ Plus Anaerobic System). For the latter conditions, the medium was supplemented with

$14821.4 \mathrm{mM} \mathrm{NaNO}$. Several colonies were picked and cultured in the Methylophaga 1403 liquid

149 medium under oxic or anoxic conditions for 2-7 days. After restreaking three times onto agar

150 medium, isolates were tested for growth under anoxic conditions. $\mathrm{NO}_{3}{ }^{-}$and $\mathrm{NO}_{2}{ }^{-}$consumption

151 was measured after 4 days of incubation. Identification of the isolates was determined by

152 extracted total DNA from the isolates, followed by PCR amplification of the 16S ribosomal

153 RNA (rRNA) genes (forward primer 5'-AGAGTTTGATCCTGGCTCAG-3' and reverse primer

154 5'-AAGGAGGTGATCCAGCCGCA-3', which correspond to positions 8 to 27 and 1521 to 1540

155 in the Escherichia coli $16 \mathrm{~S}$ rRNA gene) and the sequencing of the resulting PCR products

156 (McGill University and Genome Quebec Innovation Center, Montréal QC, Canada).

157

158 Planktonic pure cultures

159 M. nitratireducenticrescens GP59 and JAM1 were cultured in the Methylophaga medium 1601403 as described by Villeneuve et al. (15) with $0.3 \%$ methanol. When required, $\mathrm{NO}_{3}^{-}\left(\mathrm{NaNO}_{3}\right)$ 161 was added to the medium. For the anoxic cultures, $70-\mathrm{ml}$ vials with $30 \mathrm{ml}$ medium were flushed 162 with pure nitrogen gas for $20 \mathrm{~min}$, sealed with sterile septum caps and autoclaved. Culture 163 bottles were incubated at $30^{\circ} \mathrm{C}$ (unless stated otherwise) in the dark. In the determination of 164 optimal growth conditions, the $\mathrm{pH}$, temperature and $\mathrm{NaCl}$ concentrations were adjusted in the 165 Methylophaga medium 1403. For $\mathrm{N}_{2} \mathrm{O}$ measurements, 720 -mL bottles with 60-ml medium were 166 used. For oxic cultures, cultures were performed in Erlenmeyer flaks and shaken at $150 \mathrm{rpm}$ and $16730^{\circ} \mathrm{C}$ (18). Bacterial growth was monitored by spectrophotometry $\left(\mathrm{OD}_{600 \mathrm{~nm}}\right)$. Bacterial flocs 168 were dispersed with a Potter-Elvehjem homogenizer prior to measurements when needed. 
170

171 The frozen samples of the biofilm taken from the denitrification system and of the

172 acclimated biofilm taken after the $5^{\text {th }}$ transfer were thawed, and washed 3 times with $0.5 \mathrm{~mL}$ the

173 TEN buffer (50 mM Tris- $\mathrm{HCl}$ pH 8.0, $10 \mathrm{mM}$ EDTA.2Na, $\mathrm{NaCl} 150 \mathrm{mM})$ and $5000 \mathrm{~g}$

174 centrifugation for $2 \mathrm{~min}$. The biomass was dispersed in $0.5 \mathrm{~mL}$ TEN with lysozyme $(2.5 \mathrm{mg} / \mathrm{mL})$

175 and incubated at $37^{\circ} \mathrm{C}, 30 \mathrm{~min}$. After adding sodium dodecyl sulfate and $\beta$-mercaptoethanol

176 (final concentrations of $2 \%$ and $1 \%$, respectively), the biomass was subjected to three cycles of

177 freeze-thaw (10 min dry ice/ethanol bath, followed by $5 \mathrm{~min}$ at $65^{\circ} \mathrm{C}$ ), then treated with

178 proteinase $\mathrm{K}\left(50 \mu \mathrm{g} / \mathrm{mL}\right.$ final concentration) at $45^{\circ} \mathrm{C}$ for $2 \mathrm{~h}$, and finally with RNAse A (20

$179 \mu \mathrm{g} / \mathrm{mL}$ final concentration) at $37^{\circ} \mathrm{C}$ for $15 \mathrm{~min}$. The DNA was purified by extractions with

$180 \mathrm{phenol} / \mathrm{chloroform} /$ isoamyl alcohol (25:24:1 v/v) and chloroform/isoamyl alcohol (49:1), and by

181 precipitation with 0.25 volume of $10 \mathrm{M}$ ammonium acetate and 2 volumes of ethanol $95 \%$ (25).

182 DNA concentration was determined by the quantiFluor dsDNA system (Promega, Madison,

183 USA). Quantitative PCR (qPCR) was performed with SYBR green in $20-\mu \mathrm{L}$ volume with the

184 Fast Start essential DNA Green Master (Roche Diagnostics, Laval, QC, Canada) containing 200

$185 \mu \mathrm{M}$ of primers (Table 1) and $50 \mathrm{ng}$ biofilm DNA. The amplifications were performed at $95^{\circ} \mathrm{C}$ for

$18610 \mathrm{~min}$, followed by 40 cycles at $95^{\circ} \mathrm{C}$ for $20 \mathrm{~s}$, at the annealing temperature (Table 1) for $20 \mathrm{~s}$,

187 and at $72^{\circ} \mathrm{C}$ for $15 \mathrm{~s}$. After amplifications, specificity of the PCR products and the presence of

188 primer dimers were verified by performing a melt curve by increasing the temperature from $65^{\circ} \mathrm{C}$

189 to $95^{\circ} \mathrm{C}$ by increments of $1^{\circ} \mathrm{C}$ per step with a pause of $5 \mathrm{~s}$ for each step. Reactions were

190 performed in a Rotor-Gene 6000 real-time rotary analyzer (Qiagen Inc. Toronto, ON, Canada).

191 The amplification efficiencies for all primer pairs varied between 0.9 and 1.1 . The copy number

192 of each gene per ng of biofilm was calculated according to standard curves using dilutions of a 
193 gel-purified, PCR-amplified fragment of the corresponding genomic region of strain JAM1

$194(\operatorname{tag} H)$ or of strain GP59 (nirK) (Table 1), or using dilution of the NL23 genomic DNA (napA) or

195 the JAM1 genomic DNA (narG1) as the template.

Genome sequencing and annotations

High molecular weight total DNA was extracted from GP59 and JAM1 pure cultures with

the DNeasy Blood \& Tissue Extraction Kit according to the manufacturer (Qiagen, Hilden,

201 Allemagne). DNA samples were sent to the Genome Quebec Innovation Center for genome

202 sequencing and assembly by using the PacBio technology. Genome assembly used was the

203 HGAP workflow version April 2016 (26). Coverage was over 260 times with both genomes.

204 Genome assembly was checked manually with the DNASTAR software (version 14.1)

205 (Madison, WI, USA) for confirming or correcting pseudogenes. Gene annotations for the JAM1

206 genome were updated accordingly (Genbank accession number CP003390.3, National Center for

207 Biotechnology Information [NCBI] https://www.ncbi.nlm.nih.gov/). For the GP59 genome, gene

208 annotations were performed at NCBI (GenBank accession number CP021973). Annotations were

209 also performed for both genomes at the Rapid Annotation using Subsystem Technology (RAST)

210 web site (http://rast.nmpdr.org/seedviewer.cgi) and used for further analyses $(27,28)$.

211 Alignment between GP59 and JAM1 genomes was performed at RAST and with the

212 Mauve Multiple Genome Alignment version 20150226 (progressive alignment) (29). The

213 resulting alignments were corrected manually to precisely determine the common and unique

214 genes, but also the intergenic sequences. Riboswitches and non coding RNA (ncRNA) sequences

215 were determined by the NCBI annotation system. The average nucleotide identity (ANI) analysis 
216 was performed at http://enve-omics.ce.gatech.edu/ani/ with window size $1000 \mathrm{bp}$, step size 200

217 bp, minimum identity $70 \%$, minimum length $700 \mathrm{bp}$, minimum alignment $50(30,31)$. Genomes

218 were analysed for tandem repeats at https://tandem.bu.edu/trf/trf.html (32).

NirK Phylogenetic analysis

221

The deduced amino acid sequence of the GP59 nirK was compared with public protein 222 databases by BLASTP at the NCBI web site to retrieve the closest NirK sequences. These

223

224

225

226

227

228

229

230

231

232

233

234

235

236

237

238

sequences were than aligned with Cobalt (33). Evolutionary analysis was conducted using MEGA6.06 (34) with the Maximum Likelihood method based on the Le_Gascuel_2008 model (35). Initial tree(s) for the heuristic search were obtained automatically by applying NeighborJoin and BioNJ algorithms to a matrix of pairwise distances estimated using a JTT model, and then selecting the topology with superior log likelihood value. A discrete Gamma distribution was used to model evolutionary rate differences among sites $(5$ categories $[+\mathrm{G}$, parameter $=$ $0.8954])$. The analysis involved 21 amino acid sequences. There were a total of 378 positions in the final dataset.

\section{The transcriptomes of M. nitratireducenticrescens GP59 and JAM1}

Anoxic cultures of strains GP59 and JAM1 were performed in triplicate in the Methylophaga medium 1403 supplemented with $21.4 \mathrm{mM} \mathrm{NaNO}_{3}$. Cells were harvested when $\mathrm{NO}_{3}^{-}$was almost reduced in all cultures. Total RNA extraction, RNA processing, cDNA sequencing and transcriptome analyses were described by Mauffrey et al. (19), with the exception that we used Transcripts Per Million (TPM) for normalization instead of Reads Per Kilobase Million. One replicate culture of strain GP59 generated inconsistent results and was not 
239 considered in the transcriptome analyses. Intergenic regions were also considered in the

240 transcriptome analyses to detect possible missed annotated genes or non-coding expressed

241 sequences. An intergenic region includes the sequence from the stop codon of a gene to the start

242 codon of the adjacent gene. This sequence was then trimmed of 50 nucleotides at both ends to

243 exclude as much as possible the transcript reads that would belong to the adjacent genes.

244 Significance for difference in gene expression in the corresponding genes/sequences (defined as

245 TPM) between strain JAM1 (triplicate cultures) and strain GP59 (duplicate cultures) was

246 performed with the R Bioconductor NOIseq package v2.14.0 (NOIseqBio with replicates and

$247 \mathrm{q}=0.9$ ) (36) and run with the R software v3.2.3 (37). Genes/sequences of one strain that had $>2$ -

248 fold higher level of TPM than the other strain showed significant differences. RNA-seq reads

249 were deposited in the Sequence Read Archive (SRA) under the numbers SRP066381 (strain

250 JAM1) and SRP132510 (strain GP59) at NCBI.

251

252 Results and Discussion

253 Biofilm acclimation to batch cultures

254 The biofilm of the denitrification system (operated under continuous mode) was dispersed

255 in vials containing 20 Bioflow carriers, the same used in the denitrification system, and cultured

256 under anoxic, batch-mode conditions with $\mathrm{NO}_{3}{ }^{-}$. Only the carriers with the growing biofilm were

257 then transferred each week in fresh medium and cultured under the same conditions (see Material

$258 \&$ Methods section, Fig. S1). At the end of the $5^{\text {th }}$ transfer culture when the $\mathrm{NO}_{3}^{-}$and $\mathrm{NO}_{2}{ }^{-}$

259 consumption rates stabilized, the buildup of biofilm was enough (Fig. S2) to extract total DNA

260 and to perform culture assays on agar plates.

$261 \mathrm{NO}_{3}^{-}$and $\mathrm{NO}_{2}^{-}$concentrations were measured at regular interval times during the $5^{\text {th }}$ 
262 transfer culture. Complete reduction of $\mathrm{NO}_{3}{ }^{-}$and $\mathrm{NO}_{2}{ }^{-}\left(\mathrm{NO}_{\mathrm{x}}\right)$ was achieved within $15 \mathrm{~h}$, at 1.8

$263 \mathrm{mM} \mathrm{NO}_{\mathrm{x}} \mathrm{h}^{-1}$ (Fig. 1). This is 5-times faster than what was measured by Laurin et al. (24) with 60

264 Bioflow carriers taken directly from the denitrification reactor that operated under continuous-

265 mode conditions $\left(0.37 \mathrm{mM} \mathrm{NO}_{\mathrm{x}} \mathrm{h}^{-1}\right.$ or $\left.5.2 \mathrm{NO}_{\mathrm{x}}-\mathrm{N} \mathrm{L}^{-1} \mathrm{~h}^{-1}\right)$. This result suggests that changes

266 occurred in the microbial population of the batch biofilm cultures. qPCR assays were performed

267 to determine the concentrations of $M$. nitratireducenticrescens JAM1 (narG1-targeted primers)

268 and H. nitrativorans NL23 (napA-targeted primers) in the original and acclimated biofilm. In the

269 original biofilm, strain JAM1 was at $2.5 \pm 0.6 \times 10^{4}$ narGl-copies/ng biofilm DNA and $H$.

270 nitrativorans NL23 at $6.2 \pm 0.4 \times 10^{5}$ napA-copies/ng biofilm DNA. In the acclimated biofilm,

271 the concentration of strain JAM1 increased by one order of magnitude $\left(3.8 \pm 0.9 \times 10^{5}\right.$ narG1-

272 copies/ng biofilm DNA), but decreased substantially for strain NL23 $\left(2.0 \pm 0.5 \times 10^{2}\right.$ napA-

273 copies/ng biofilm DNA). With the decrease of strain NL23 and the increase of strain JAM1 in

274 the acclimated biofilm with a gain of denitrification performance, we hypothesized that a 275 subpopulation of $M$. nitratireducenticrescens that can perform the complete denitrification 276 pathway was enriched in the acclimated biofilm.

277

278

Strain GP59 displaced H. nitrativorans NL23 and M. nitratireducenticrescens JAM1

279 The acclimated biofilm from the $5^{\text {th }}$ transfer cultures was dispersed and cultured onto a 280 Methylophaga specific medium, and several isolates were screened for $\mathrm{NO}_{3}^{-}$and $\mathrm{NO}_{2}^{-}$ 281 consumption. One isolate, which we named strain GP59, was capable to consume $\mathrm{NO}_{3}^{-}$and $282 \mathrm{NO}_{2}^{-}$, and cultures showed gas production, suggesting full denitrifying activities by this strain. 283 The 16S rRNA gene sequence of strain GP59 has $100 \%$ identity to that of $M$. 284 nitratireducenticrescens JAM1. 
287 primers targeted strain-specific sequences (tagH for strain JAM1 and nirK for strain GP59) were

288 developed based on their respective genome (Table 1; see below). The GP59 cell concentrations

went from undetected (below limit of PCR detection) in the original biofilm to high level in the acclimated biofilm at $2.2 \pm 0.35 \times 10^{5}$ nirK-copies/ng biofilm DNA. This is $2-3$ orders of

magnitude higher than that of strain JAM1 $\left(4.0 \pm 1.7 \times 10^{2}\right.$ tagH-copies/ng biofilm DNA). These

292 results confirm our hypothesis that a new M. nitratireducenticrescens strain with full 293 denitrification capacity occurred in the acclimated biofilm, and displaced $H$. nitrativorans NL23, 294 but also $M$. nitratireducenticrescens JAM1. Comparative analyses were then performed between 295 strain GP59 and M. nitratireducenticrescens JAM1 at the physiological, genomic and 296 transcriptomic levels.

\section{Physiological characterization of strain GP59}

Strain GP59 cultured under anoxic conditions (planktonic pure cultures) showed a 24-h lag before growth occurred (Fig. 2a). The growth yields reached about $1.2 \mathrm{OD}_{600 \mathrm{~nm}}$ with $42.8 \mathrm{mM}$

$301 \mathrm{NO}_{3}^{-}$exposure and did not increase significantly in cultures exposed with higher $\mathrm{NO}_{3}^{-}$

302 concentrations. Strain JAM1 cultured under the same conditions showed no lag phase, and 303 growth yields were 3- to 6-fold lower than those of the GP59 cultures (Fig. 2a). The maximum 304 specific growth rate $(\mu \max )$ and the half-saturation constants of $\mathrm{NO}_{3}{ }^{-}$for growth $(\mathrm{Ks})$ were 305 calculated (Table 2). The $\mu$ max for strain GP59 is higher (3.3 times) than that of strain JAM1. To assess the affinity of strain GP59 toward $\mathrm{NO}_{3}{ }^{-}$for growth, the $\mu \mathrm{max} / \mathrm{Ks}$ ratio was calculated (38)

307 (Table 2). This ratio $\left(1.2 \mu \mathrm{M}^{-1} \mathrm{NO}_{3}{ }^{-} \mathrm{h}^{-1}\right)$ is not different than the one calculated for strain JAM1 
308 at $1.3 \mu \mathrm{M}^{-1} \mathrm{NO}_{3}{ }^{-} \mathrm{h}^{-1}$ (19). These results concur with the genome sequences (see below) with near

$309100 \%$ identity between the two strains in gene clusters encoding the two Nar systems and the

$310 \mathrm{NO}_{3}{ }^{-}$transporters (NarK).

311 As observed with growth, a 24h-lag period was observed in the GP59 cultures before $\mathrm{NO}_{3}{ }^{-}$

312 started to be consumed, whereas $\mathrm{NO}_{3}{ }^{-}$consumption appeared in the JAM1 cultures within $24 \mathrm{~h}$

313 (Fig. 2b). The $\mathrm{NO}_{3}{ }^{-}$reduction rates increased linearly with the increase of $\mathrm{NO}_{3}{ }^{-}$concentrations

314 in the GP59 cultures (Fig. 3a). The specific $\mathrm{NO}_{3}{ }^{-}$reduction rates (rates normalized by the

315 biomass) averaged around 1.5 to $2 \mathrm{mM} \mathrm{NO}_{3}{ }^{-} \mathrm{h}^{-1} \mathrm{OD}^{-1}$ and showed no significant changes at any

$316 \mathrm{NO}_{3}{ }^{-}$concentrations tested (Fig. 3b). In the JAM1 cultures, the $\mathrm{NO}_{3}{ }^{-}$reduction rates reached a

317 plateau at $24 \mathrm{mM} \mathrm{NO}_{3}^{-}$(Fig. 3a), and, as observed with the GP59 cultures, showed no significant

318 changes in the specific $\mathrm{NO}_{3}{ }^{-}$reduction rates (averaged around 4 to $6 \mathrm{mM} \mathrm{NO}_{3}{ }^{-} \mathrm{h}^{-1} \mathrm{OD}^{-1}$ ) (Fig.

319 3b). Interestingly, these specific rates are 2.4 to 5.4-fold higher than those of strain GP59, 320 suggesting that the JAM1 cells have a higher dynamism of $\mathrm{NO}_{3}{ }^{-}$processing (e.g. $\mathrm{NO}_{3}{ }^{-}$intake 321 and reduction) than the GP59 cells. Close examination of the respective genomes and 322 transcriptomes (see below) did not reveal specific gene(s) that would explain these differences.

$323 \mathrm{~N}_{2} \mathrm{O}$ was detected in the GP59 anoxic cultures and reached maximum accumulation ( $c a$.

$3240.5 \mu$ mol $\mathrm{N}_{2} \mathrm{O}$ vial ${ }^{-1}$ or $0.04 \% \mathrm{~N}$-input) when $\mathrm{NO}_{2}^{-}$peaked in the medium, and then decreased in 325 concentration afterwards (Fig. 2b). This result concurs with the presence of a complete 326 denitrification pathway in strain GP59 as revealed by its genome sequence (see below).

327 Strain GP59 was cultured under oxic conditions with different concentrations of $\mathrm{NO}_{3}{ }^{-}(9.6$

328 to $142.8 \mathrm{mM}$ ). Contrary to the JAM1 cultures that can reduce $\mathrm{NO}_{3}^{-}$to $\mathrm{NO}_{2}^{-}$under oxic 329 conditions (19), no $\mathrm{NO}_{3}{ }^{-}$consumption was observed in the GP59 cultures at any tested 330 concentrations. These latter results, coupled with the 24-h lag period before nitrate reduction 
331 occurs in the GP59 anoxic cultures, suggest that strains GP59 and JAM1 regulate differently the

332 expression of their denitrification genes.

333 Both strains cannot grow on methylamine and fructose. They showed similar growth

334 profile related to $\mathrm{NaCl}$ concentrations (optimal growth at 1 to $5 \% \mathrm{NaCl}$; weaker growth at $8 \%$;

335 no growth at 0 and $10 \%$ ), $\mathrm{pH}$ (optimal growth at $\mathrm{pH} 8$; weaker growth at $\mathrm{pH} \mathrm{7,9}$ and 10; no

336 growth at $\mathrm{pH} 6$ and 11) and temperature (optimal growth at $30^{\circ} \mathrm{C}$; variability in culture replicates

337 at 22 and $34{ }^{\circ} \mathrm{C}$; weak growth at $37^{\circ} \mathrm{C}$ ). Sensibility to antibiotics by strain GP59 was also similar

338 to those reported by Villeneuve et al. (15) for strain JAM1 (chloramphenicol, trimethoprim,

339 ampicillin, tetracycline, streptomycin, gentamycin and kanamycin).

340

341

342 The genome of strain GP59 contains nirK

343 The genome of strain GP59 was sequenced by the PacBio technology. Although strain

344 JAM1 was already sequenced by the pyrosequencing technology, it was resequenced by the

345 PacBio technology to correct some discrepancies in the genome assembly (Supplemental Data1).

346 Analysis of the GP59 genome revealed the presence of two prophages (named GPMu1 and

347 GPMu2) integrated side by side in the same orientation and separated by $11102 \mathrm{nt}$ (Supplemental

348 Data2). The intercalated sequence has a GC content of $40.1 \%$, which is lower than in the overall

349 genome (44.8\%). Gene arrangement of the prophages resembles to that of the E. coli phage $\mathrm{Mu}$

350 and of the Haemophilus influenzae FluMu prophage (39). Gene clusters encoding Mu-type

351 prophage proteins are also present in the genome of two Methylophaga species such as $M$.

352 frappieri JAM7 that was also isolated from the original biofilm of the denitrification system (12)

353 (Supplemental Data2). No prophage was found in the JAM1 genome. 
of 363 amino acid residues (Supplemental Data2). Upstream of this nirK, is a gene encoding the

356 NO reductase activation protein NorD. The precise function of NorD is yet to be known, but the

357 norD mutant in Paracoccus denitrificans showed no activity of the $c d_{1}$-type $\mathrm{NO}_{2}^{-}$reductase

358 (NirS) and of the NO reductase (40). Available genomic sequences from other Methylophaga

359 species and from metagenomic studies were screened for the presence of genes encoding NirK

360 highly similar to the GP59 NirK. The closest affiliations of the GP59 NirK are with NirK

361 encoded in three reconstituted Methylophaga sp. genomes from a metagenomic study of marine

362 subsurface aquifer samples (NCBI Bioproject PRJNA391950 by Tully, Wheat, Glazer and

363 Huber, University of Southern California) (Fig. 4). These three NirK have 84-85\% similarity

364 with the GP59 NirK sequence. In addition, norD is also present adjacent to nirK in these three

365 Methylophaga sp. genomes.

366 The previous results suggest that there are Methylophaga strains in natural environments

367 that carry denitrification modules. We further performed data mining to retrieve denitrification

368 genes in available genomes of Methylophaga species or in reconstituted Methylophaga genomes

369 from metagenomics studies. Data provided by the Bioproject PRJNA391950 revealed that the

370 metagenome of the Methylophaga sp. isolate NORP53 (accession number NVVW00000000)

371 contains two gene clusters with one (contig NVVW01000003) having the same gene

372 arrangement of the Nar1 gene cluster in the JAM1 and GP59 genomes (narXL, NarK1K2GHJ),

373 and another one (NVVW01000010) encoding a $\mathrm{N}_{2} \mathrm{O}$ reductase (nosRZDFYL). At the amino acid

374 sequence level, these gene clusters of isolate NORP53 are 67 to $90 \%$ similar with the

375 corresponding gene products in the JAM1 and GP59 genomes. Finally, nirK sequences were

376 found in the genome of M. frappieri JAM7 and of 34 Methylophaga sp. retrieved from 
377 metagenomics studies (Supplemental Data3). Although M. frappieri JAM7 does not grow under

378 anoxic conditions with $\mathrm{NO}_{3}^{-}$, which concurs with the absence gene cluster encoding a

379 dissimilatory $\mathrm{NO}_{3}{ }^{-}$reductase, the occurrence of nirK may be associated with the detoxification

380 mechanism. All these results suggest that the different denitrification modules are carried by

381 some Methylophaga species present in natural environments.

382

383 Strain GP59 belongs to the species Methylophaga nitratireducenticrescens

384 Table 3 summaries the overall features of the GP59 and JAM1 genomes. Both genomes

385 share 2790 coding sequences (CDS) and 11 riboswitches (Supplemental Data4). The $67 \mathrm{kbp}$

386 chromosomic region containing the denitrification gene clusters narl, nar2, norl, nor 2 and nos

387 (19) is $99.94 \%$ identical (43 substitutions, no gap) between the two strains. Based on the genome

388 annotations, functions associated with CDS that are unique to strain JAM1 have in most cases an

389 equivalent in strain GP59. In addition to CDS associated with the two prophages and the

390 intercalated sequence, the GP59 genome has CDS associated with an integrated plasmid

391 (position 724937 to 765476 ; Supplemental Data4). The GC skew between the two genomes is

392 relatively similar (Fig. S3). Two-way ANI analysis showed $99.30 \%$ identity, and $>80 \%$

393 conserved sequences between the two genomes, indicating that both strains belong to the same

394 species $(30,31)$.

395 Both genomes have small tandem repeats with $>10$ repeats positioned at equivalent

396 locations. These tandem repeats vary in number of repeats between the two strains (Table 3), and

397 are located in CDS with no putative known function. A long tandem repeat (four 3095-nt

398 repeats) were found in the GP59 genome (Table 3). Genes encoding an aspartate

399 aminotransferase and a TonB-dependent siderophore receptor are among the three genes 
400 repeated 4 times. The equivalent region in the JAM1 genome shows no repetition, with 93\%

401 identity with the 3095-nt repeat sequence with most of the divergence in the TonB-dependent

402 siderophore receptor gene.

403 Strain GP59 contains two plasmids here named pGP32 and pGP34 (Table 3). These

404 plasmids encode type IV secretion system as observed in many plasmids hosted by Gram 405 negative bacteria (Supplemental Data5) (41). They also carry genes encoding for recombinases, 406 nucleases, DNA methyltransferases, toxin/antitoxin, and carbon storage regulator. These two 407 plasmids show no homology with the integrated plasmid in the GP59 genome. M. frappieri 408 JAM7 also carries a $48.5 \mathrm{~kb}$ plasmid, which resembles in its structure to the IncPalpha plasmids 409 (Supplemental Data5). It shares no homology with the pGP32 and pGP34 plasmids.

411 M. nitratireducenticrescens GP59 did not evolve from M. nitratireducenticrescens JAM1

412 Did strain GP59 evolve during the acclimation process of the biofilm from strain JAM1

413 that underwent series of chromosomic rearrangements and phage infections, or was strain GP59

414 present in the original biofilm and enriched during the acclimation? To try to answer this 415 question, we analyzed the Clustered Regularly Interspaced Short Palindromic Repeats (CRISPR) 416 region that has been identified in the GP59 and JAM1 genomes. The CRISPR system is an 417 adaptive immunity system that is present in most archaea and many bacteria and that acts against 418 invading genetic elements, such as bacteriophages and plasmids. The chromosomic arrangement 419 of CRISPR system includes CRISPR associated genes (cas), a leader sequence upstream of an 420 array of short repeats interspersed with unique spacers that are almost identical to fragments of 421 bacteriophage and plasmid genes. The transcription of the spacer array provides complementary 422 DNA targeting, for instance, phage genome resulting in target DNA degradation (42-44). 
423 Addition of new spacers in response, for instance, of bacteriophage infection occurs proximal to

424 the leader sequence. Accordingly, CRISPR spacers provide a historical perspective of phage 425 exposure, with spacers at the vicinity of the leader were relatively recently added, and those 426 distal spacers likely originated from previous events (45).

The CRISPR region in GP59 and JAM1 genomes comprises 5 associated CRISPR genes 428 (Fig. 5a). Except for the spacer sequences, the nucleotide sequence of the CRISPR genes and the 429 repeat sequences are identical in both genomes (Fig. 5a, c). There are 105 and 115 spacers in the 430 JAM1 and GP59 CRISPR regions, respectively (Fig. 5b). In the JAM1 CRISPR region, 14 431 spacer sequences were found twice. The GP59 and JAM1 CRISPR regions share 29 spacer 432 sequences (Fig. 5b); all of them are distal to the leader sequence (the most ancient acquired 433 sequences (45)). No spacer sequence was found twice in the GP59 CRISPR region. As both 434 CRISPR regions do not share sequence between their proximal spacers, strains GP59 and JAM1 435 underwent a different history of phage infections from a common ancestry. This strongly 436 suggests that strain GP59 did not originate from strain JAM1 that underwent series of 437 chromosomic rearrangements and phage infections in a short period of time and in a closed 438 environment, but rather was present in the original biofilm and was enriched during the 439 acclimation phase of the biofilm.

440 The GP59 and JAM1 CRISPR regions were also compared to other available 441 Methylophaga genomes. M. frappieri JAM7 contains 68 repeat units. The repeat sequence has 442 one-nt substitution with the GP59/JAM1 one (Fig 5c). None of its spacer sequences were found 443 in the GP59 and JAM1 CRISPR regions. In the M. aminisulfidivorans MP, M. sulfidovorans 444 DSM 11578, M. lonarensis MPL genomes, 59, 6 and 63 spacer sequences were found, 445 respectively; none were repeated twice or were found in other Methylophaga species. 
The CRISPR genes and gene arrangement in $M$. frappieri JAM7 are typical of the subtype

447 I-F CRISPR-Cas system, whereas those of M. aminisulfidivorans MP, M. sulfidovorans DSM

448 11578, M. lonarensis MPL are related to the subtype I-E one (Fig 5a) (44). In strains GP59 and

449 JAM1, the CRISPR genes and gene arrangement cannot be associated to a defined subtype.

450 However, the gene arrangement and the deduced amino acid sequences of cas 3 and of the two

451 downstream CDS are highly similar to CRISPR genes found in several bacterial genomes such as

452 Legionella brunensis (GenBank accession number LNXV01000004) and Moraxella atlantae

453 (GenBank accession number LZMZ01000013).

\section{Transcriptome analyses}

456 The GP59 and JAM1 genomes share more than $85 \%$ of their genes. However, gene 457 variations, the presence of strain-specific genes, and the occurrence of plasmids in strain GP59 458 could affect the expression pattern of these common genes. To assess whether these genes were expressed differently between strains GP59 and JAM1, the transcriptome of both strains was derived from anoxic cultures at the end of the exponential growth when $\mathrm{NO}_{3}{ }^{-}$was nearly 461 completely reduced in both cultures. Among the 2857 common genes (CDS and ncRNA), more 462 than $85 \%$ of those in strain GP59 showed no significant difference in the transcription levels $(<2-$ 463 fold difference in TPM) (Supplemental Data4) with their counterparts in strain JAM1. The vast 464 majority of genes involved in the nitrogen pathway were expressed in equivalent levels in both 465 strains (Table 4). The fact that the cultures were sampled for RNA extraction when both strains

466 were at an equivalent physiological phase (anoxic conditions with nitrate almost consumed) 467 could explain this high proportion of similar gene expression between the two strains. Among 468 genes with significant differences are those encoding the synthesis of the osmoprotectant ectoine, 
469 which were 3 to 6 -fold higher in the JAM1 cultures than in the GP59 cultures (Fig. S4). This

470 suggests that strain JAM1 could be more resilient to changes in salinity.

471 The most expressed genes were sorted out from both transcriptomes to assess which

472 specific metabolic pathways are the most solicited under denitrifying conditions. High levels of

473 gene expression were found in both strains for genes involved in growth, energy and respiration

474 (e.g. ribosomal proteins, ATP synthase, pseudoazurin), and the C-1 metabolic carbon such as

475 methanol dehydrogenase, ribulose monophosphate enzymes (D-arabino-3-hexulose 6-phosphate

476 formaldehyde-lyase, 6-phospho-3-hexuloisomerase), formaldehyde activating enzymes.

477 (Supplemental Data6, Fig. S4). One of the highest expressed genes in both genomes is located in

478 the chromosomic region comprising three adjacent genes encoding similar proteins $(>88 \%$

479 similarity). Each of these genes has a cyclic di-GMP riboswitch in their respective upstream

480 sequence. The first of the three genes showed high level of TPM in the riboswitch and in the

481 coding sequence (Table 5). The other two genes and their respective riboswitch showed much

482 lower expression levels. The deduced amino acid sequence of these three similar proteins

483 contains a carbohydrate-binding module 6 that is found in carbohydrate-active enzymes such as

484 glycoside hydrolases (46), and three transmembrane domains. Upstream and downstream of

485 these three genes are genes encoding proteins involved in polysaccharide export and in the

486 capsular polysaccharide biosynthesis. These proteins may participate in this synthesis. Finally,

487 the pGP32 plasmid accounted for $23.1 \%$ of total TPM in the GP59 transcriptomes, whereas it

488 was $0.7 \%$ for the pGP34 plasmid (Supplemental Data6). In the pGP32 plasmid, nine genes

489 accounted for $20 \%$ of total TPM, among which are genes involved in restriction-modification

490 systems (Supplemental Data6).

491 


\section{Conclusions}

493 Culturing the denitrifying biofilm under batch conditions has favored the enrichment of a 494 new denitrifying subpopulation, representing by M. nitratireducenticrescens GP59 that displaced

$495 H$. nitrativorans NL23 and $M$. nitratireducenticrescens JAM1. In addition of complete 496 denitrification by strain GP59, two important differences were observed between the two strains.

497 Strain GP59 cannot reduce $\mathrm{NO}_{3}^{-}$under oxic conditions as does strain JAM1, and a $24 \mathrm{~h}$ lag 498 period was observed in GP59 anoxic cultures before growth and nitrate reduction occurs. These 499 results suggest differences in regulation of the denitrification genes between the two strains. The 500 genome of strain GP59 showed insertions of two Mu-type prophages that probably brought a 501 nirK gene, the missing denitrification gene in strain JAM1. Both genomes share more than $85 \%$ 502 of their genes, and these genes were expressed at similar level under anoxic conditions at the end 503 of the exponential growth. Finally, analysis of the CRISPR region suggests that strain GP59 did 504 not originate from strain JAM1, but was present in the original biofilm and was enriched during 505 the acclimation process.

506 These comparative analyses between strains GP59 and JAM1 unveiled that $M$.

507 nitratireducenticrescens species enriched in the biofilm of the bioreactor encompasses a mosaic

508 population structure. Although plasticity of the genomic landscape of bacterial species resulting

509 to gene rearrangements, point mutations and lateral gene acquisition was observed in nature (47,

510 48), the observation of M. nitratireducenticrescens GP59 reported here shows functional

511 consequences of population variation on process rate and system performances. The reason why

512 strain GP59 did occur in the acclimated biofilm but not in the Biodome denitrification system

513 remains obscure and is under investigation. This could be related to the batch-mode conditions

514 where the transient accumulation of $\mathrm{NO}_{2}^{-}$(up to $10 \mathrm{mM}$; Fig. 1) could have adverse the growth 
515 of $H$. nitrativorans NL23, favoring the enrichment of $M$. nitratireducenticrescens GP59. In the

516 denitrification reactor at the Biodome, such accumulation of $\mathrm{NO}_{2}^{-}$was not encountered probably

517 due the continuous-operating mode or the lower denitrification rates that prevailed.

518 Our study broadens the ecology of $M$. nitratireducenticrescens with the occurrence of a

519 microbial seedbank suited for anoxic conditions. So far among the genus Methylophaga, M.

520 nitratireducenticrescens is the only reported species that can grow under anoxic conditions.

521 Based on metagenomics studies, however, where denitrification genes were found in

522 Methylophaga-reconstituted genomes, this anoxic metabolism within this genus is more

523 widespread than previously thought. Methanol is generated by anthropogenic activities or by

524 biogenic metabolisms such as plant growth and decomposition, and ocean ecosystems are

525 thought to participate actively in its production. Furthermore, oceans are known to be a sink of 526 atmospheric methanol $(49,50)$. As they are ubiquitous in marine environments, Methylophaga 527 spp. are therefore important actors in the methanol turnover on Earth, either under oxic 528 environments (surface ocean) or, based on our studies with M. nitratireducenticrescens, under 529 anoxic marine environments (deep ocean).

530

531 Acknowledgments

532 We thank Karla Vasquez for her technical assistance.

533

\section{References}

535 1. Van Spanning RJM, Delgado MJ, Richardson DJ. 2005. The nitrogen cycle: 536 denitrification and its relationship to $\mathrm{N}_{2}$ fixation, p. 277-342. In Werner DNewton WE 
537 (ed.), Nitrogen Fixation in Agriculture, Forestry, Ecology, and the Environment. Springer

$538 \quad$ Netherlands.

539 2. Einsle O, Kroneck PM. 2004. Structural basis of denitrification. Biol Chem 385:875$540 \quad 883$.

541 3. Zumft WG. 1997. Cell biology and molecular basis of denitrification. Microbiol Mol $542 \quad$ Biol Rev 61:533-616.

543 4. Kaspar HF. 1982. Nitrite reduction to nitrous-oxide by Propionibacteria - Detoxication 544 Mechanism. Arch Microbiol 133:126-130.

545 5. Poole R. 2005. Nitric oxide and nitrosative stress tolerance in bacteria. Biochemical Soc $546 \quad$ T 33:176-180.

547 6. Schreiber F, Wunderlin P, Udert KM, Wells GF. 2012. Nitric oxide and nitrous oxide 548 turnover in natural and engineered microbial communities: biological pathways, chemical 549 reactions, and novel technologies. Front Microbiol 3: 372.

550 7. Simon J, Klotz MG. 2013. Diversity and evolution of bioenergetic systems involved in 551 microbial nitrogen compound transformations. Bba-Bioenergetics 1827:114-135.

552 8. Labbé N, Juteau P, Parent S, Villemur R. 2003. Bacterial diversity in a marine 553 methanol-fed denitrification reactor at the Montreal Biodome, Canada. Microbial Ecol 46:12-21.

9. Laurin V, Labbé N, Parent S, Juteau P, Villemur R. 2008. Microeukaryote diversity in a marine methanol-fed fluidized denitrification system. Microbial Ecol 56:637-648.

557 10. Labbé N, Laurin V, Juteau P, Parent S, Villemur R. 2007. Microbiological 558 community structure of the biofilm of a methanol-fed, marine denitrification system, and identification of the methanol-utilizing microorganisms. Microbial Ecol 53:621-630. 
560 11. Rissanen AJ, Ojala A, Dernjatin M, Jaakkola J, Tiirola M. 2016. Methylophaga and

561 Hyphomicrobium can be used as target genera in monitoring saline water methanol-

562 utilizing denitrification. J Ind Microbiol Biotechnol 43:1647-1657.

563 12. Auclair J, Lepine F, Parent S, Villemur R. 2010. Dissimilatory reduction of nitrate in 564 seawater by a Methylophaga strain containing two highly divergent narG sequences. $565 \quad$ Isme J 4:1302-1313.

566 13. Auclair J, Parent S, Villemur R. 2012. Functional diversity in the denitrifying biofilm 567 of the methanol-fed marine denitrification system at the Montreal Biodome. Microbial $568 \quad$ Ecol 63:726-735.

569 14. Martineau C, Villeneuve C, Mauffrey F, Villemur R. 2013. Hyphomicrobium nitrativorans sp. nov., isolated from the biofilm of a methanol-fed denitrification system treating seawater at the Montreal Biodome. Int J Syst Evol Microbiol 63:3777-3781.

572 15. Villeneuve C, Martineau C, Mauffrey F, Villemur R. 2013. Methylophaga 573 nitratireducenticrescens sp. nov. and Methylophaga frappieri sp. nov., isolated from the biofilm of the methanol-fed denitrification system treating the seawater at the Montreal Biodome. Int J Syst Evol Microbiol 63:2216-2222.

576 16. Martineau C, Mauffrey F, Villemur R. 2015. Comparative analysis of denitrifying activities of Hyphomicrobium nitrativorans, Hyphomicrobium denitrificans, and Hyphomicrobium zavarzinii. Appl Environ Microbiol 81:5003-5014.

579 17. Martineau C, Villeneuve C, Mauffrey F, Villemur R. 2013. Complete genome 580 sequence of Hyphomicrobium nitrativorans strain NL23, a denitrifying bacterium isolated from biofilm of a methanol-fed denitrification system treating seawater at the Montreal Biodome. Genome Announc 2: e01165-13. 
583 18. Mauffrey F, Cucaita A, Constant P, Villemur R. 2017. Denitrifying metabolism of the

584 methylotrophic marine bacterium Methylophaga nitratireducenticrescens strain JAM1.

$585 \quad$ Peerj 5: 4098.

586 19. Mauffrey F, Martineau C, Villemur R. 2015. Importance of the two dissimilatory (Nar)

587 nitrate reductases in the growth and nitrate reduction of the methylotrophic marine 588 bacterium Methylophaga nitratireducenticrescens JAM1. Front Microbiol 6:1475.

589 20. Villeneuve C, Martineau C, Mauffrey F, Villemur R. 2012. Complete genome 590 sequences of Methylophaga sp. strain JAM1 and Methylophaga sp. strain JAM7. J $591 \quad$ Bacteriol 194:4126-4127.

592 21. Boden R. 2012. Emended description of the genus Methylophaga Janvier et al. 1985. Int $593 \quad$ J Syst Evol Microbiol 62:1644-1646.

594 22. Labelle M-A. 2004. Optimisation d'un bioprocédé de dénitrification d'un sytème 595 aquacole marin en circuit fermé au Biodôme de Montréal. Master thesis. École $596 \quad$ Polytechnique de Montréal.

597 23. Labbé N, Parent S, Villemur R. 2003. Addition of trace metals increases denitrification 598 rate in closed marine systems. Water Res 37:914-920.

599 24. Laurin V, Labbe V, Juteau P, Parent S, Villemur R. 2006. Long-term storage 600 conditions for carriers with denitrifying biomass of the fluidized, methanol-fed 601 denitrification reactor of the Montreal Biodome, and the impact on denitrifying activity 602 and bacterial population. Water Res 40:1836-1840.

603 25. Sambrook JF, Russell DW (ed.). 2001. Molecular Cloning: A Laboratory Manual. Cold 604 Spring Harbor Laboratory Press. 
605 26. Chin CS, Alexander DH, Marks P, Klammer AA, Drake J, Heiner C, Clum A,

606 Copeland A, Huddleston J, Eichler EE, Turner SW, Korlach J. 2013. Nonhybrid,

607 finished microbial genome assemblies from long-read SMRT sequencing data. Nat

$608 \quad$ Methods 10:563-569.

609 27. Aziz RK, Bartels D, Best AA, DeJongh M, Disz T, Edwards RA, Formsma K,

610 Gerdes S, Glass EM, Kubal M, Meyer F, Olsen GJ, Olson R, Osterman AL,

611 Overbeek RA, McNeil LK, Paarmann D, Paczian T, Parrello B, Pusch GD, Reich C,

612 Stevens R, Vassieva O, Vonstein V, Wilke A, Zagnitko O. 2008. The RAST server:

613 Rapid annotations using subsystems technology. Bmc Genomics 9: 75.

614 28. Overbeek R, Olson R, Pusch GD, Olsen GJ, Davis JJ, Disz T, Edwards RA, Gerdes

615 S, Parrello B, Shukla M, Vonstein V, Wattam AR, Xia FF, Stevens R. 2014. The

616 SEED and the Rapid Annotation of microbial genomes using Subsystems Technology

617 (RAST). Nucleic Acids Res 42:D206-D214.

618 29. Darling ACE, Mau B, Blattner FR, Perna NT. 2004. Mauve: Multiple alignment of

619 conserved genomic sequence with rearrangements. Genome Res 14:1394-1403.

620 30. Goris J, Konstantinidis KT, Klappenbach JA, Coenye T, Vandamme P, Tiedje JM.

621 2007. DNA-DNA hybridization values and their relationship to whole-genome sequence 622 similarities. Int J Syst Evol Microbiol 57:81-91.

623 31. Rodriguez-R LM, Konstantinidis KT. 2016. The enveomics collection: a toolbox for 624 specialized analyses of microbial genomes and metagenomes. PeerJ Preprints 4:e1900v1.

625 32. Benson G. 1999. Tandem repeats finder: a program to analyze DNA sequences. Nucleic $626 \quad$ Acids Res 27:573-580. 
627 33. Papadopoulos JS, Agarwala R. 2007. COBALT: constraint-based alignment tool for 628 multiple protein sequences. Bioinformatics 23:1073-1079.

629 34. Tamura K, Stecher G, Peterson D, Filipski A, Kumar S. 2013. MEGA6: Molecular 630 Evolutionary Genetics Analysis Version 6.0. Mol Biol Evol 30:2725-2729.

631 35. Le SQ, Gascuel O. 2008. An improved general amino acid replacement matrix. Mol Biol $632 \quad$ Evol 25:1307-1320.

633 36. Tarazona S, Garcia-Alcalde F, Dopazo J, Ferrer A, Conesa A. 2011. Differential 634 expression in RNA-seq: A matter of depth. Genome Res 21:2213-2223.

635 37. Team RC. 2015. A language and environment for statistical computing. R Foundation 636 for Statistical Computing, Vienna, Austria. URL https://www.R-project.org/.

637 38. Healey FP. 1980. Slope of the monod equation as an indicator of advantage in nutrient 638 competition. Microbial Ecol 5:281-286.

639 39. Morgan GJ, Hatfull GF, Casjens S, Hendrix RW. 2002. Bacteriophage Mu genome 640 sequence: Analysis and comparison with Mu-like prophages in Haemophilus, Neisseria and Deinococcus. J Mol Biol 317:337-359.

642

40. DeBoer APN, VanderOost J, Reijnders WNM, Westerhoff HV, Stouthamer AH, 643 VanSpanning RJM. 1996. Mutational analysis of the nor gene cluster which encodes 644 nitric-oxide reductase from Paracoccus denitrificans. Eur J Biochem 242:592-600.

645 41. Christie PJ. 2001. Type IV secretion: intercellular transfer of macromolecules by 646 systems ancestrally related to conjugation machines. Mol Microbiol 40:294-305.

647 42. Barrangou R, Marraffini LA. 2014. CRISPR-Cas systems: Prokaryotes upgrade to 648 adaptive immunity. Mol Cell 54:234-244. 
649 43. Garneau JE, Dupuis ME, Villion M, Romero DA, Barrangou R, Boyaval P,

650 Fremaux C, Horvath P, Magadan AH, Moineau S. 2010. The CRISPR/Cas bacterial

immune system cleaves bacteriophage and plasmid DNA. Nature 468:67-+.

652 44. Makarova KS, Haft DH, Barrangou R, Brouns SJJ, Charpentier E, Horvath P, 653 Moineau S, Mojica FJM, Wolf YI, Yakunin AF, van der Oost J, Koonin EV. 2011. 654 Evolution and classification of the CRISPR-Cas systems. Nat Rev Microbiol 9:467-477.

655 45. Horvath P, Romero DA, Coute-Monvoisin AC, Richards M, Deveau H, Moineau S, 656 Boyaval P, Fremaux C, Barrangou R. 2008. Diversity, activity, and evolution of 657 CRISPR loci in Streptococcus thermophilus. J Bacteriol 190:1401-1412.

658 46. Henshaw JL, Bolam DN, Pires VMR, Czjzek M, Henrissat B, Ferreira LMA, Fontes 659 CMGA, Gilbert HJ. 2004. The family 6 carbohydrate binding module CmCBM6-2 660 contains two ligand-binding sites with distinct specificities. J Biol Chem 279:21552$661 \quad 21559$.

662 47. Allen EE, Tyson GW, Whitaker RJ, Detter JC, Richardson PM, Banfield JF. 2007. 663 Genome dynamics in a natural archaeal population. Proc Natl Acad Sci USA 104:1883$664 \quad 1888$.

665 48. Bendall ML, Stevens SLR, Chan LK, Malfatti S, Schwientek P, Tremblay J, 666 Schackwitz W, Martin J, Pati A, Bushnell B, Froula J, Kang DW, Tringe SG, 667 Bertilsson S, Moran MA, Shade A, Newton RJ, McMahon KD, Malmstrom RR. 2016. Genome-wide selective sweeps and gene-specific sweeps in natural bacterial populations. Isme J 10:1589-1601.

670 49. Galbally IE, Kirstine W. 2002. The production of methanol by flowering plants and the 671 global cycle of methanol. J Atmos Chem 43:195-229. 
672 50. Millet DB, Jacob DJ, Custer TG, de Gouw JA, Goldstein AH, Karl T, Singh HB,

673 Sive BC, Talbot RW, Warneke C, Williams J. 2008. New constraints on terrestrial and

674 oceanic sources of atmospheric methanol. Atmos Chem Phys 8:6887-6905.

675 


\section{Figure 1 (on next page)}

$\mathrm{NO}_{3}{ }^{-}$and $\mathrm{NO}_{2}{ }^{-}$reduction by the acclimated biofilm

The biofilm was batch-cultured under anoxic conditions. After the $5^{\text {th }}$ transfer, the $\mathrm{NO}_{3}{ }^{-}$and $\mathrm{NO}_{2}{ }^{-}$concentrations were measured over different time intervals. $\mathrm{NO}_{x}$ : combined measurements of $\mathrm{NO}_{3}{ }^{-}$and $\mathrm{NO}_{2}{ }^{-}$. Each point is the average with standard deviation of triplicate cultures. 


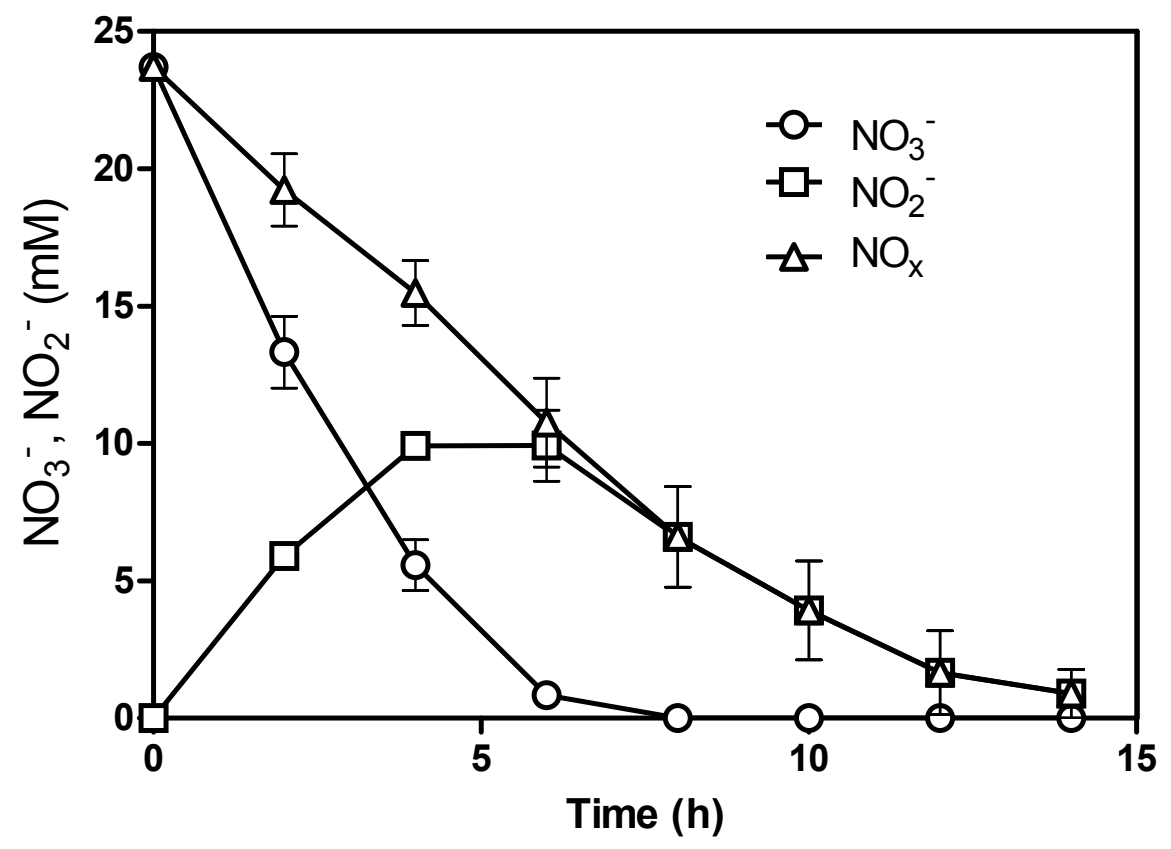


Figure 2 (on next page)

Growth, and $\mathrm{NO}_{3}^{-}, \mathrm{NO}_{2}^{-}$and $\mathrm{N}_{2} \mathrm{O}$ dynamics by Methylophaga nitratireducenticrescens GP59 and JAM1

Panel a. Growth. Strain GP59 and strain JAM1 were cultured under anoxic conditions with 9.6 or $42.8 \mathrm{mM} \mathrm{NO}_{3}{ }^{-}$. Panel b: $\mathrm{NO}_{3}{ }^{-}, \mathrm{NO}_{2}{ }^{-}$and $\mathrm{N}_{2} \mathrm{O}$ dynamics. Strain GP59 and strain JAM1 were cultured under anoxic conditions with $21.4 \mathrm{mM} \mathrm{NO}_{3}{ }^{-}$, and $\mathrm{NO}_{3}{ }^{-}, \mathrm{NO}_{2}{ }^{-}$and $\mathrm{N}_{2} \mathrm{O}$ were measured over different time intervals. Each point is the average with standard deviation of triplicate cultures for Panel $a$, and of duplicate cultures for Panel $b$. 

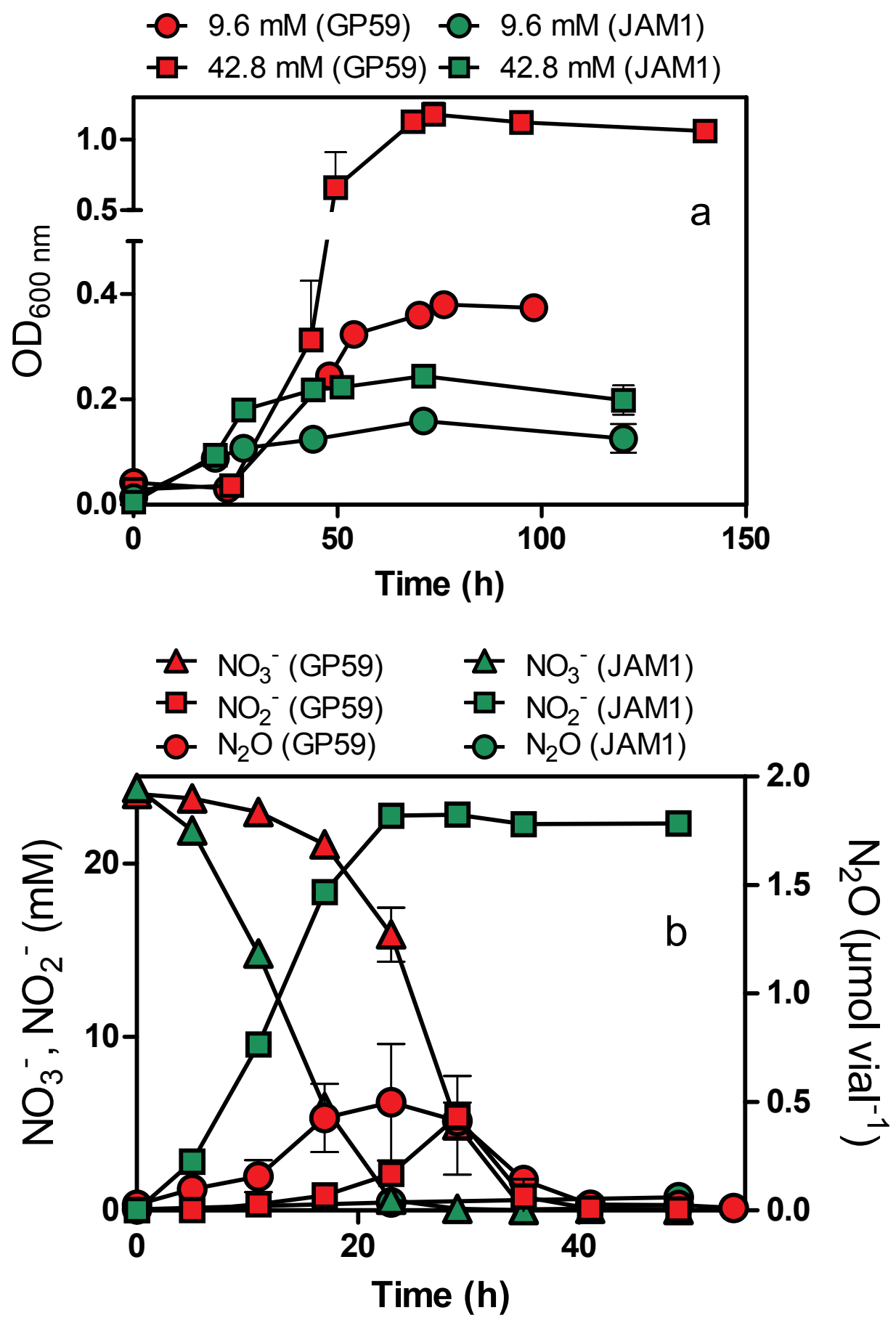


\section{Figure 3 (on next page)}

Specific $\mathrm{NO}_{3}^{-}$reduction rates

Panel a: $\mathrm{NO}_{3}{ }^{-}$reduction rates of strains GP59 and JAM1. Each point is the average with standard deviation of triplicate anoxic cultures. Panel b: Specific $\mathrm{NO}_{3}{ }^{-}$reduction rates. These rates were calculated with the $\mathrm{NO}_{3}{ }^{-}$reduction rates by the generated culture biomass $\left(\mathrm{OD}_{600 \mathrm{~nm}}\right)$ at the end of the exponential phase. 

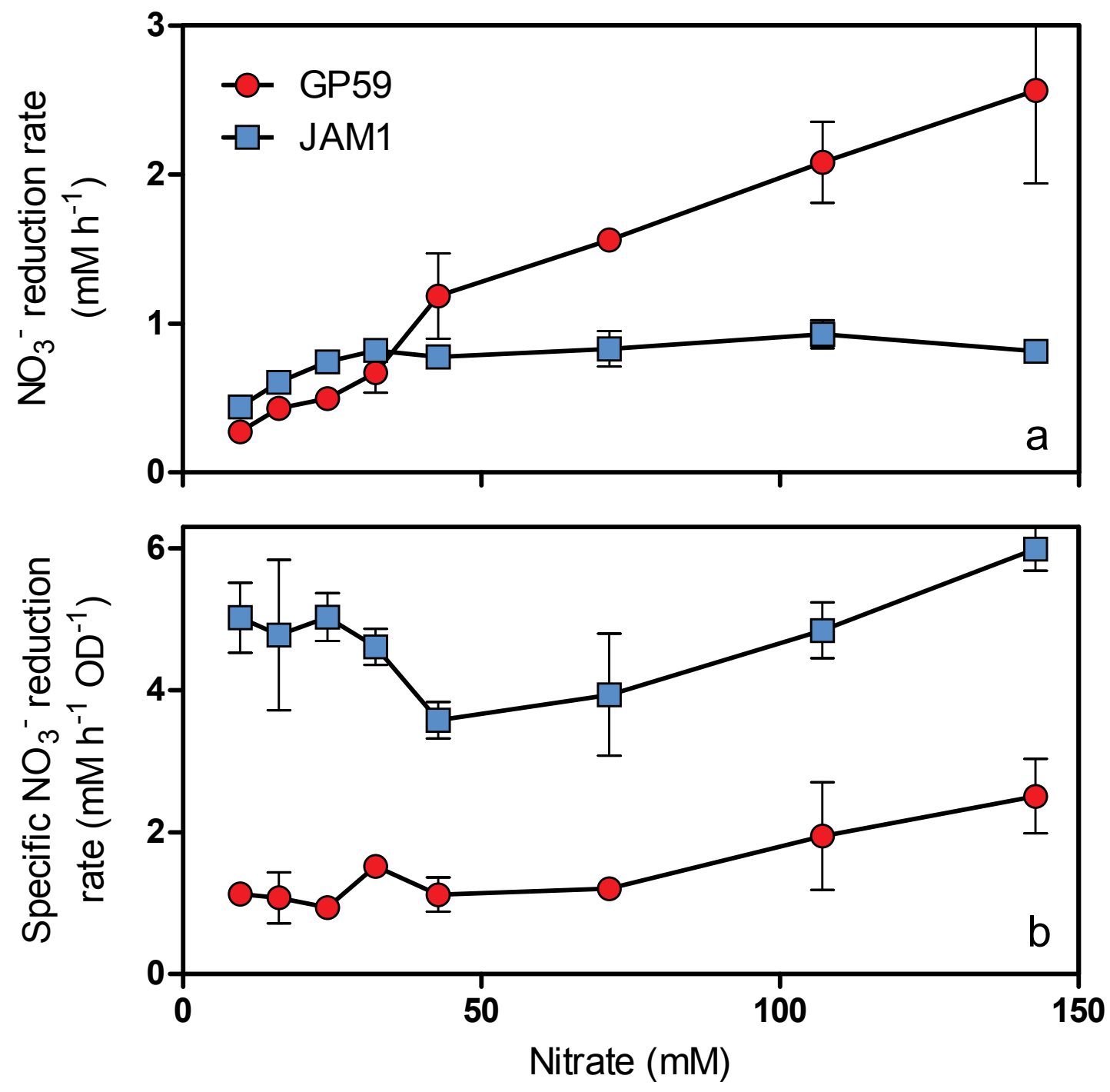


\section{Figure 4 (on next page)}

Phylogenetic analysis of NirK of Methylophaga nitratireducenticrescens GP59

An unrooted phylogenetic tree demonstrating the evolutionary relationship of NirK deduced amino acid sequences is illustrated. The evolutionary history was inferred by using the Maximum Likelihood and the tree with the highest log likelihood (-7598.4857) is shown. The percentage (values above 70\%) of trees in which the associated taxa clustered together is shown next to the branches (bootstrap analysis with 1000 replicates). The tree is drawn to scale, with branch lengths measured in the number of substitutions per site. The GenBank accession number is provided after each bacterial name. *: The Cycloclasticus sp. NORP92, Gammaproteobacterium NORP60, and the Methylophaga sp. NORP93, NORP33 and NORP65 are from the NCBI bioproject PRJNA391950 by Tully, Wheat, Glazer and Huber, University of Southern California. 


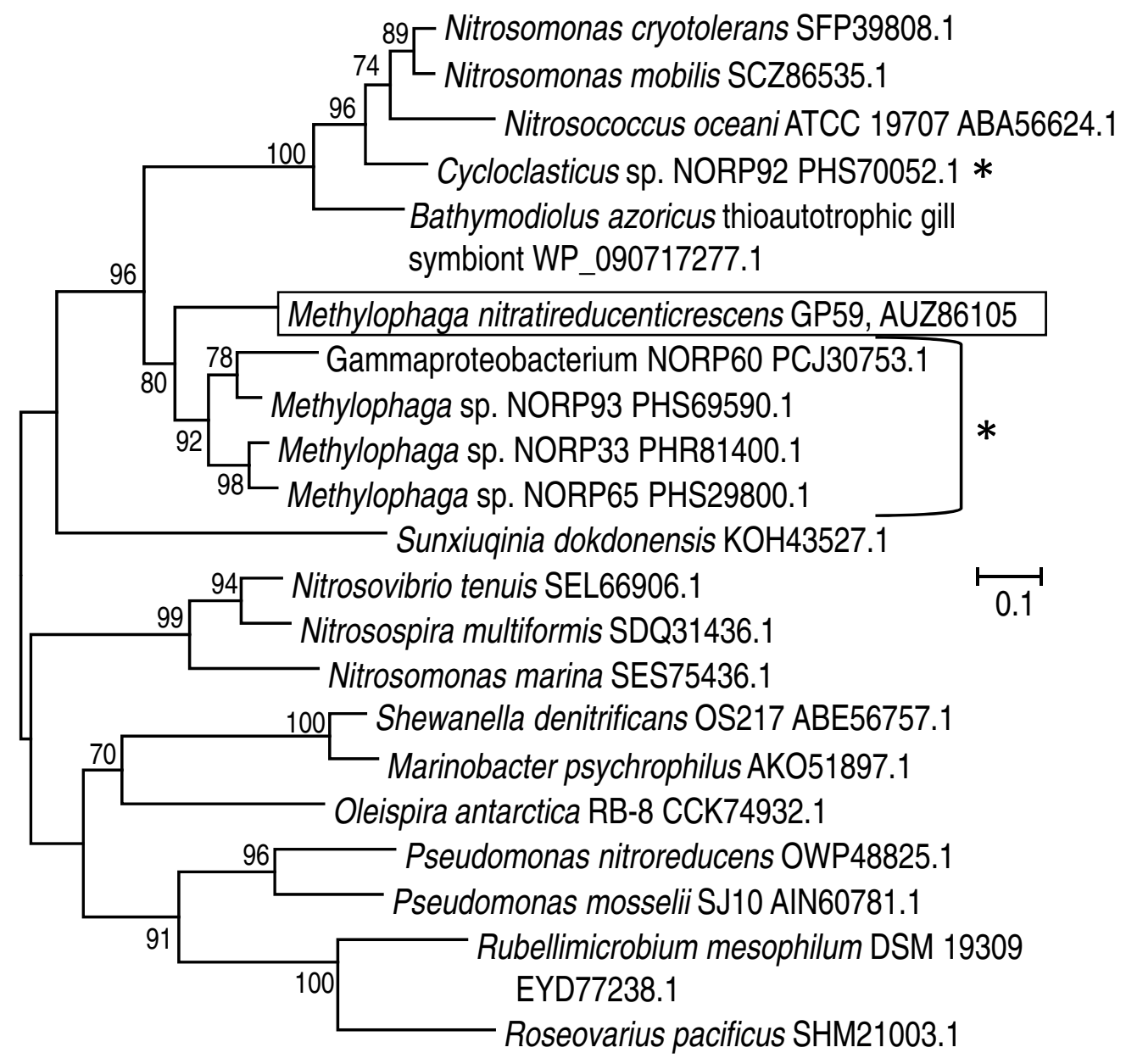




\section{Figure 5 (on next page)}

CRISPR chromosomic arrangement in Methylophaga genomes

Panel a. Gene arrangement. Sequences were retrieved from GenBank. Accession numbers:

M. nitratireducenticrescens JAM1: CP003390 (Q7A_2613 to Q7a_2609) and GP59: CP021973

(CDW43_11545 to CDW43_11525); M. frappieri JAM7 CP003380 (Q7C_1045 to Q7C_1040); M. aminisulfidivorans MP: NZ_AFIG01000001 (MAMP_RS08465 to MAMP_RS08425), M.

sulfidovorans DSM 11578: FOSH01000003 (SAMN04488079_1032 to SAMN04488079_10310); M. Ionarensis MPL, APHR01000054 (MPL1_10022 to MPL1_10062). Nomenclature is based on Makarova et al. (42). HP: Hypothetical protein. Numbers at the right are the number of repeat units with the repeat/spacer nucleotide length in parentheses. Panel b. Spacer/repeat unit arrangement. Blue: The 29 common units. Green: The 14 units repeated twice in strain JAM1. Panel c. CRISPR repeat sequences in different Methylophaga species. 


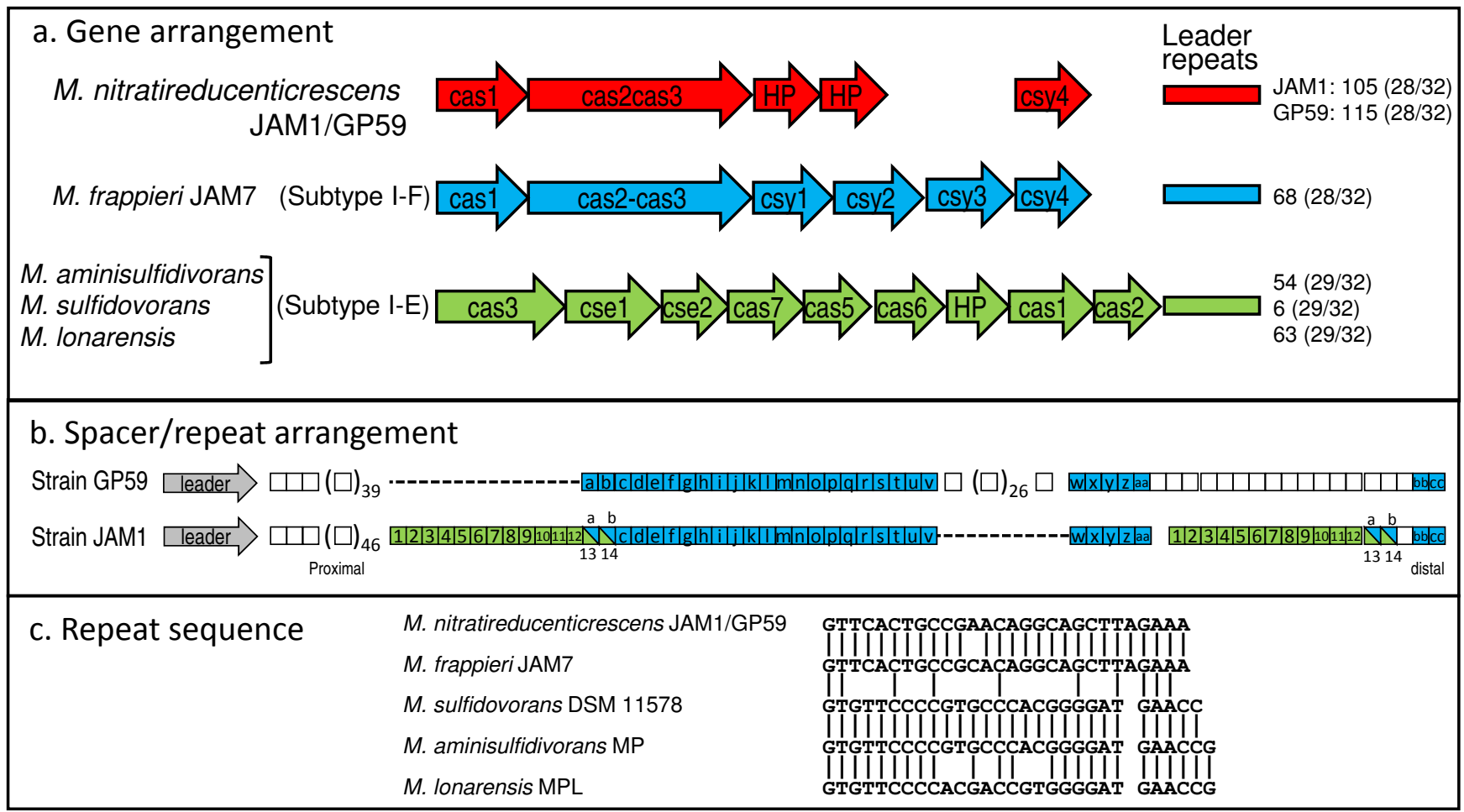


Table $\mathbf{1}$ (on next page)

PCR primers used for qPCR assays 


\section{Table 1: PCR primers used for qPCR assays}

2

3

Gene $\quad$ Sequence $\left(5^{\prime}-3^{\prime}\right)$

target

Annealing

Fragment Comment

temperature $\left({ }^{\circ} \mathrm{C}\right)$ length (nt)

narG1 (strain JAM1/GP59; locus Q7A 446). Nitrate reductase subunit alpha (Nar1 system) narG1 AGCCCACATCGTATCAAGCA narG1 CCACGCACCGCAGTATATTG

$61-149$

qPCR

tagH (strain JAM1, locus tag: Q7A 1110). Teichoic acid export ATP-binding protein* TagH Forward CCGTCATTTCGCTTCAAGAT

55 TCATGGCTTTTTCAGCCTTT

10 TagH Reverse

11 qTagH Forward

12 qTagH Reverse GTTGCAAGGCTATAGTCGGAGT

55 TGGTACGCATTCCAGATGAATA

13

nirK (strain GP59, loc

\begin{abstract}
NirK Forward
\end{abstract}
CGTTCAATACATGGGGTAAAGG $\frac{\text { 15165). Copper containing nitrite reductase }}{55}$

NirK Reverse TGGGGCACAGTGATAAACAA

qNirK Forward qNirK Reverse AAGTCGGTAAAGTAGCCGTTGA 55 TCTCCATCGTCATTTGAACAAC

napA (strain NL23, locus tag W911 13875) periplasmic nitrate reductase qnapA Forward AGGACGGGCGGATCAATTTT 61 711 Standard qnapA Reverse CGGATATGCATCGGACACGA

131 $1134 \quad$ Standard

*The function was deduced by RAST annotations.

GenBank accession number of the genome of strain JAM1: CP003390.3, strain GP59: 
Table 2 (on next page)

Kinetics of growth under anoxic conditions 
1 Table 2. Kinetics of growth under anoxic conditions

2

\begin{tabular}{lll}
\cline { 2 - 3 } 4 & Strain GP59 & Strain JAM1* \\
\cline { 2 - 2 }$\left(\mathrm{h}^{-1}\right)$ & $0.0380(0.0027)$ & $0.0116(0.0008)$
\end{tabular}

$5 \mathrm{Ks}(\mathrm{mM}) \quad 30.7(5.8) \quad 9.2(1.9)$

$6 \mu \max / \mathrm{Ks}\left(\mu \mathrm{M}^{-1} \mathrm{~h}^{-1}\right) \quad 1.2(0.2) \quad 1.3(0.3)$

$7 \mu$ max, maximum growth rates. Ks, half-saturation constants of

$8 \mathrm{NO}_{3}{ }^{-}$for growth. Values between parentheses are standard

9 deviation of triplicates. * from Mauffrey et al. (19). 


\section{Table 3(on next page)}

Genomic features of $M$. nitratireducenticrescens strains JAM1 and GP59 


\begin{tabular}{|c|c|c|c|}
\hline & JAM1 & \multicolumn{2}{|l|}{ GP59 } \\
\hline \multicolumn{4}{|l|}{ Genome } \\
\hline Length (nt) & 3137100 & \multicolumn{2}{|c|}{3238484} \\
\hline GC content $(\%)$ & 44.75 & \multicolumn{2}{|c|}{44.86} \\
\hline CDS\& & 3027 & \multicolumn{2}{|l|}{$3187^{\$}$} \\
\hline Common CDS & 2790 & \multicolumn{2}{|l|}{2790} \\
\hline tRNA & 44 & \multicolumn{2}{|l|}{44} \\
\hline rRNA (5S-16S-23S) & 9 & \multicolumn{2}{|l|}{9} \\
\hline ncRNA & 4 & \multicolumn{2}{|l|}{4} \\
\hline \multicolumn{4}{|c|}{ (TmRNA, SRP-RNA, RNase P, 6S RNA) } \\
\hline Riboswitch & 11 & \multicolumn{2}{|l|}{11} \\
\hline \multicolumn{4}{|l|}{ Small Tandem Repeats* } \\
\hline TCAGYCA & $16(785393)$ & \multicolumn{2}{|c|}{$12(710616)$} \\
\hline CTTCGG & $55(2294123)$ & \multicolumn{2}{|c|}{$19(2287110)$} \\
\hline GGYTCT & $39(2660735)$ & \multicolumn{2}{|c|}{$37(2669276)$} \\
\hline \multicolumn{4}{|l|}{$\underline{\text { Large tandem repeat }}{ }^{\mathfrak{E}}$} \\
\hline 3095-nt repeats & $1\left(1940231 ; 93 \%{ }^{£}\right)$ & \multicolumn{2}{|c|}{$4\left(1904086 ; 100 \% \%^{\mathfrak{f}}\right)$} \\
\hline Plasmids & None & pGP32 & pGP34 \\
\hline Length (nt) & & 32421 & 33560 \\
\hline GC content $(\%)$ & & 44.29 & 44.13 \\
\hline
\end{tabular}

27 \&Based on RAST annotations

$28{ }^{\$}$ The possible CDS in the ambiguous region of GPMu1 were not taking into account.

29 Common CDS: see supplemental Data4.

30 *Number of copies. Genome location under parenthesis. Only repeats with more than $31 \quad 10$ copies are presented.

32 EN Number of copies. Genome location under parenthesis. \% identity between the 309533 nt long repeats (see text). 


\section{Table 4(on next page)}

Relative expression of selected genes under anoxic culture conditions 


\section{Table 4. Transcript levels of genes involved in the nitrogen pathway in Methylophaga nitratireducenticrescens JAM1 and GP59}

\begin{tabular}{|c|c|c|c|c|}
\hline \multirow{2}{*}{ Locus Tag } & \multirow{2}{*}{ Gene/function } & \multirow{2}{*}{$\begin{array}{c}\text { *Expression ratio } \\
\text { JAM1/GP59 } \\
\end{array}$} & \multicolumn{2}{|c|}{$* *$ mxaI $=100$} \\
\hline & & & GP59 & JAM1 \\
\hline \multicolumn{5}{|l|}{ Nitric oxide reductase 1} \\
\hline CDW43 RS01925-40 & nor $C B D Q$ & 0.93 & 11.7 & 12.4 \\
\hline CDW43_RS01945 & norR & 1.42 & 4.9 & 6.8 \\
\hline CDW43_RS01950 & norE & 0.84 & 7.8 & 6.5 \\
\hline \multicolumn{5}{|c|}{ Nitrate reductase $\overline{1}$ (with transporters and regulators) } \\
\hline CDW43 RS01975-80 & narXL & 2.07 & 3.8 & 7.9 \\
\hline CDW43_RS01985-2010 & narK1K2narGHJI & 0.66 & 17.5 & 9.8 \\
\hline \multicolumn{5}{|c|}{ Nitrous oxide reductase } \\
\hline CDW43_RS02060-85 & $\operatorname{nos} R Z D F Y L$ & 1.51 & 5.5 & 9.0 \\
\hline \multicolumn{5}{|l|}{ Nitrate reductase $\overline{2}$ (with transporter) } \\
\hline CDW43_RS02155 & narK & 0.75 & 1.9 & 1.4 \\
\hline CDW43_RS02165-80 & narGHJI & 0.83 & 1.9 & 1.5 \\
\hline \multicolumn{5}{|l|}{ Nitric oxide reductase 2} \\
\hline CDW43_RS02185-2200 & nor $C B Q D$ & 0.83 & 2.1 & 1.7 \\
\hline \multicolumn{5}{|l|}{ Copper containing nitrite reductase } \\
\hline CDW43_RS15160 & $\operatorname{nirK}$ & na & 1.0 & na \\
\hline \multicolumn{5}{|l|}{ Nitrate assimilatory pathway } \\
\hline CDW43_RS11575 & Nitrate/nitrite transporter & 1.17 & 0.2 & 0.2 \\
\hline CDW43_RS11585 & Assimilatory nitrate reductase large sub. & 1.17 & 0.3 & 0.4 \\
\hline CDW43_RS11590 & Nitrite reductase $[\mathrm{NAD}(\mathrm{P}) \mathrm{H}]$ small sub. & 0.81 & 0.2 & 0.2 \\
\hline CDW43_RS11595 & Nitrite reductase $[\mathrm{NAD}(\mathrm{P}) \mathrm{H}]$ large sub. & 0.84 & 0.4 & 0.3 \\
\hline
\end{tabular}

Other genes involved in nitrogen pathway

\begin{tabular}{lllll} 
CDW43_RS01710 & fnr transcriptional regulator & 1.41 & 3.9 & 5.5 \\
CDW43_RS00310 & $n n r S$ protein involved in response to NO & 2.71 & 4.4 & 12.2 \\
CDW43_RS01960 & $n n r S$ & 0.99 & 7.4 & 7.3 \\
CDW43_RS08605 & $n n r S$ & 1.61 & 3.8 & 6.4 \\
CDW43_RS00315 & $n s r R$ transcriptional regulator & 1.90 & 17.4 & 33.8 \\
CDW43_RS01825 & $n s r R$ & 0.86 & 2.3 & 2.0 \\
CDW43_RS00320 & dnrN/norA/yftE NO-dependent regulator & 1.98 & 25.0 & 48.7 \\
CDW43_RS01015 & Ammonium transporter & 1.01 & 1.0 & 1.0 \\
CDW43_RS05605 & Ammonium transporter & 0.48 & 0.9 & 0.5 \\
CDW43_RS01835 & Nitric oxide dioxygenase & 0.79 & 2.7 & 2.2 \\
CDW43_RS09635 & Nitric oxide dioxygenase & 0.65 & 8.0 & 5.0 \\
CDW43_RS01010 & Nitrogen regulatory protein P-II & 0.85 & 1.2 & 1.0 \\
CDW43_RS06615 & Nitrogen regulatory protein P-II & 0.80 & 7.0 & 5.5 \\
CDW43_RS13530 & Nitrogen regulatory protein P-II & 0.74 & 1.2 & 0.8 \\
CDW43_RS01095 & Nitrogen regulation protein NtrY & 1.30 & 1.4 & 1.9 \\
CDW43_RS01100 & Nitrogen regulation protein NtrX & 1.35 & 3.6 & 4.9 \\
CDW43_RS06315 & Nitrogen regulation protein NtrB & 0.60 & 1.1 & 0.6 \\
CDW43_RS06320 & Nitrogen regulation protein NR(I) & 1.12 & 0.7 & 0.8 \\
CDW43_RS15625 & PTS IIA-like nitrogen-regulator PtsN & 0.95 & 12.1 & 11.1 \\
\hline
\end{tabular}

*Ratio of JAM1 transcripts per million (TPM) by strain GP59 TPM.

**: Transcript levels relative to the expression of the methanol dehydrogenase small unit ( $m x a I$ ) set to 100 (see supplemental doc6). For polycistronique operons, the values are the average values of individual genes.

na: not applicable 
55 Locus tag refers to the genome sequence of strain GP59 (GenBank accession number CP021973). Gene/function is 56 based on RAST annotations, see supplemental doc4.

57 


\section{Table 5 (on next page)}

Relative expression of selected genes under anoxic culture conditions 


\section{Table 5: Relative expression of selected genes under anoxic culture conditions}

\begin{tabular}{|c|c|c|c|c|}
\hline \multirow[b]{2}{*}{ Locus tag } & \multirow[b]{2}{*}{ Function } & \multirow[b]{2}{*}{ Strand } & \multicolumn{2}{|c|}{$\begin{array}{c}\text { Relative } \\
\text { Expression }\end{array}$} \\
\hline & & & $\overline{\text { GP59 }}$ & JAM1 \\
\hline CDW43_06820 & Mannose-1-phosphate guanylyltransferase & + & 2.3 & 3.5 \\
\hline CDW43_06825 & $\begin{array}{l}\text { Capsular polysaccharide synthesis enzyme CpsA, sugar transferase, } \\
\text { undecaprenyl-phosphate glucose phosphotransferase }\end{array}$ & + & 3.3 & 5.2 \\
\hline CDW43_06835 & $\begin{array}{l}\text { Cyclic di-GMP riboswitch class I } \\
\text { Hypothetical protein, carbohydrate-binding module } 6\end{array}$ & + & $\begin{array}{l}2011 \\
936\end{array}$ & $\begin{array}{l}1561 \\
777\end{array}$ \\
\hline & Cyclic di-GMP riboswitch class I & & 9.1 & 13 \\
\hline CDW43_06840 & Hypothetical protein, carbohydrate-binding module 6 & + & 7.3 & 7.6 \\
\hline CDW43_06845 & $\begin{array}{l}\text { Cyclic di-GMP riboswitch class I } \\
\text { Hypothetical protein, carbohydrate-binding module } 6\end{array}$ & + & $\begin{array}{l}6.5 \\
30\end{array}$ & $\begin{array}{l}2.9 \\
7.1\end{array}$ \\
\hline CDW43_06850 & Periplasmic protein involved in polysaccharide export & + & 6.8 & 4.6 \\
\hline CDW43_06855 & Hypothetical protein & + & 4.7 & 3.6 \\
\hline CDW43 06860 & Exopolysaccharide transport protein, putative & + & 2.6 & 2.0 \\
\hline
\end{tabular}

Gene expression is relative to mxaI set to 100 (2602 TPM for strain GP59 and 4060 TPM for

24 strain JAM1). Locus tag: from GenBank accession number CP021973. Functions are based on 25 RAST annotations. 